DE DE GRUYTER

OPEN

DOI 10.1515/pesd-2015-0019

PESD, VOL. 9, no. 1, 2015

\title{
THERMAL HAZARDS IN COLD SEMESTER OF THE YEAR IN THE MOUNTAIN AREA OF MOLDOVA RIVER (SECTOR BETWEEN VAMA AND THE SPRINGS OF MOLDOVA RIVER)
}

\author{
Apostol Liviu ${ }^{1}$, Ilie Nicolae ${ }^{2}$
}

Key words: thermal inversion, thermal hazard, rime, frost, pollution

\begin{abstract}
During the cold semester, most representative of climate risks are the thermal ones, specifically, on the base of a depression area, apprearance of thermal inversions. Amid this feature mentioned, the coldest temperatures were recorded in the lowlands, in the hearth's depression,as the municipe Câmpulung Moldovenesc, here being registered and the lowest temperature from the area studied, $-31.7^{\circ} \mathrm{C}$. All these thermal inversions that occur in transitional periods (spring and autumn) are producing the early frosts, late respectively, these being the most damaging for local agriculture. This stability of the atmosphere, in conjunction with cold air, which is garrisoned on the's hearth depression, leads to atmospheric pollution with pollutants, resulting from transport and heating, because we are talking about an area in woodland, and consequently, wood is the main source of heating, especially in outlying areas of the city Câmpulung Moldovenesc,where court houses predominate, with their own heating systems.
\end{abstract}

\section{Introduction}

The area studied is situated in the northern part of Romania, more precisely, the upper Valley of the river Moldova, on the Eastern facade of the Northern Group of the Eastern Carpathians. This layout of the studied area, as well as the high degree of fragmentation, allowing cold air masses advance,associated to eastern european anticyclone to characterize the thermal regime, and dwelling on the depression and the appearance of thermal inversions, which are, moreover, constituted the main risk during the cold semester.

\footnotetext{
${ }^{1}$ Prof. PhD. Alexandru Ioan Cuza University, Iasi, Romania

${ }^{2} \mathrm{PhD}$. student, Alexandru Ioan Cuza University, Iasi, Romania
} 


\section{Adopted metodology of the study}

For this study, we used data on the thermal values from the two meteorological stations representative for this area, namely, Câmpulung Moldovenesc and Rarău, for 1961-1998. They were centralized in a database and processed using statistical software, Microsoft Excel, and besides the data mentioned earlier, I also used material taken from the worldclim dataset, and they mediated for the mentioned period, the latest materials being processed using the software Mips v, TNT 6.9 and Global Mapper v 13.0.

\section{The obtained results}

Extreme thermal concrete values, from which one we can speak of hazard, are dependent on several factors: the show (for example the advent of frost, so thermal negative values during the early autumn or late in the spring, is a hazard that may result in destruction of crops or plants in vegetation); concrete place of manifestation (latitude, elevation, depression, hill, mountain); the intensity and duration of the phenomenon.

\section{Waves of cold and negative singularities}

Location of baric centers, the sequence and the direction of their movement, their frequency and intensity facilitate penetration of the country's territory of air masses with different properties, in this case cold air masses and dry ,which indroduce large negative deviations of the thermal regime for the cold season, especially in lowland areas of the studied zone (fig. $1 \mathrm{a}$ and $\mathrm{b}$ ).
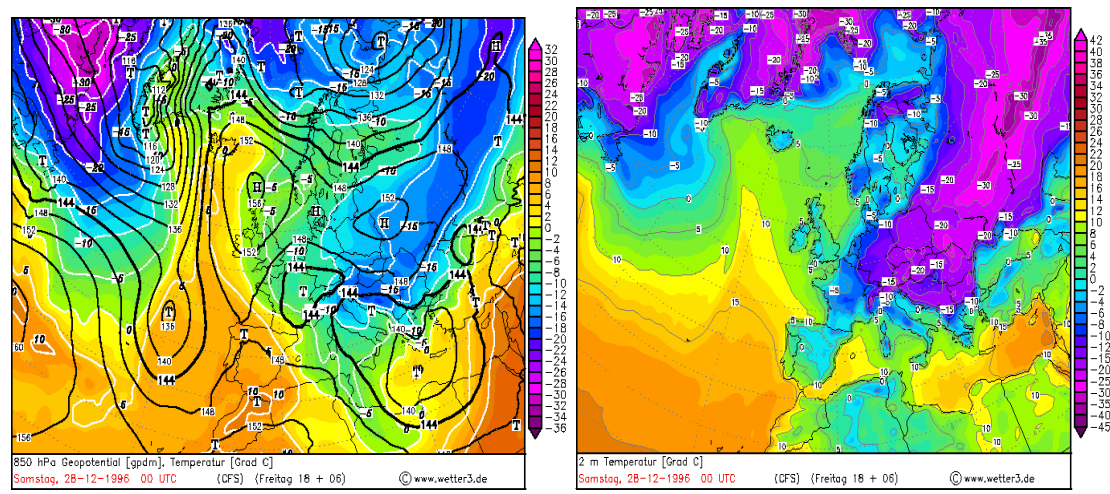

Fig. 1 Atmospheric pressure and temperature at $850 \mathrm{hPa}$ geopotential-a) and the temperature at the level of $2 \mathrm{~m} 28$ December 1996 Europe 00 UTCb)http://www.wetter3.de/Archiv/

This represents non-variations, which are combined with the organizational structure of the underlying surface and, in the case of the areas with a depressional 
relief, which makes the area studied might have to do with thermal inversions, a notion which will be aborded with risk features favored by thermal inversions.

\section{Cold massive frequency at the weather station in Câmpulung Moldovenesc}

In the monitoring interval of temperatures (1961-1998) at the weather station in Câmpulung Moldovenesc, most powerful refrigeration came forward in January, 1961, 1963, 1964, 1968, 1969, 1985, 1991, etc, and in February 1961, 1964, 1969, 1974, 1991, etc., but also in December 1961, 1964, 1972, 1976, 1983, 1988, 1993, 1996, etc. These refrigeration are produced by combining three climatic factors, namely high atmospheric pressure, low temperatures and the form of depressions.

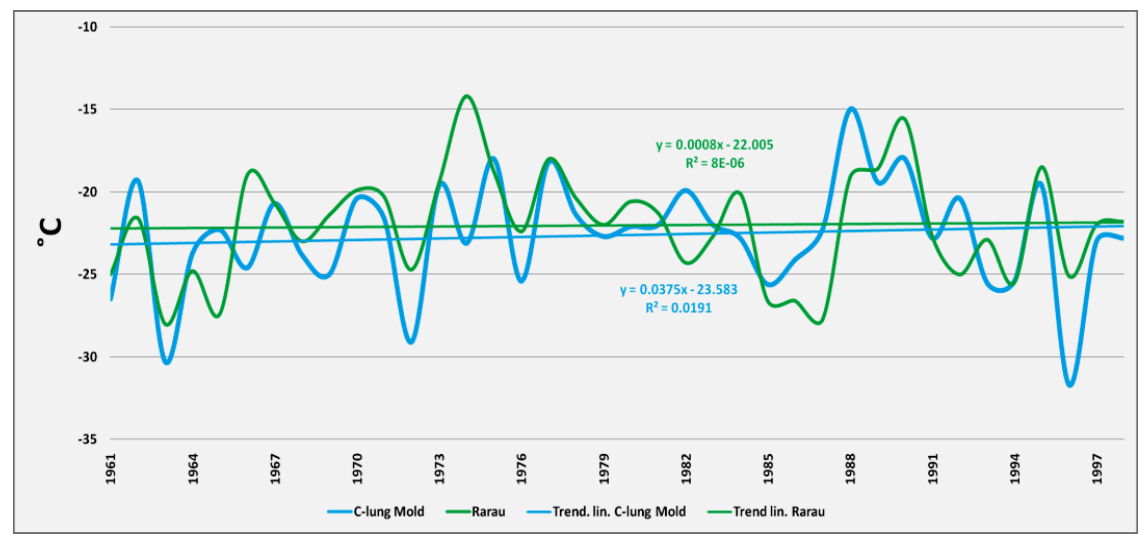

Fig. 2 The minimum absolute temperature evolution of Câmpulung Moldovenesc Rarău in the coldest month (1961-1998)

As shown on the graph with minimum absolute temperature evolution (fig. 2), in the period 1961-1998 can be seen an easy process of heating, the proof is the trendlines for both Câmpulung Moldovenesc and the Rarău mountains. However, the most powerful trend of increase in temperature is observed within the city of Câmpulung, that's because, in addition to the current global warming, influence and anthropisation in the last 20-30 years in the city.

In addition,the graph gives faithfully and processes of inversion, the most pronounced such processes have occurred during the year 1963, when on the depression's hearth were $-2.3{ }^{\circ} \mathrm{C}$ colder than the Rarău mountains. Such inversions have occurred in 1966 , when the difference was $-5.6{ }^{\circ} \mathrm{c}, 1969$ with a difference of$3.6^{\circ} \mathrm{C}, 1972$, with a difference of $-4.2^{\circ} \mathrm{C}, 1974$ with a difference of $-8.9^{\circ} \mathrm{C}, 1984$ $2.7^{\circ} \mathrm{C}, 1990-2.4^{\circ} \mathrm{C}, 1993-2.6^{\circ} \mathrm{C}, 1996-6.6^{\circ} \mathrm{C}$, the latter year being characterized and most modest absolute minimum for mun. Câmpulung Moldovenesc, where 
there have been-31.7 ${ }^{\circ} \mathrm{C}$ (28 December 1996), surpassing the previous minimum of-29.1 since 1972 , respectively, $-30.3^{\circ} \mathrm{C}$ in 1963.

\section{Temperature inversions}

At a first glance, thermal inversions seem not to fit at the climate phenomenon of risk. These climatic phenomenons through the frequency, intensity and duration, in certain conditions may cause climate risks. They can promote the supercooling of the subiacent surface.Inversions of temperature take place mostly in lowland areas, representing a common presence in the depressional area specific to Câmpulung Moldovenesc and entire valley of Moldova related to depressional area (fig. 3).

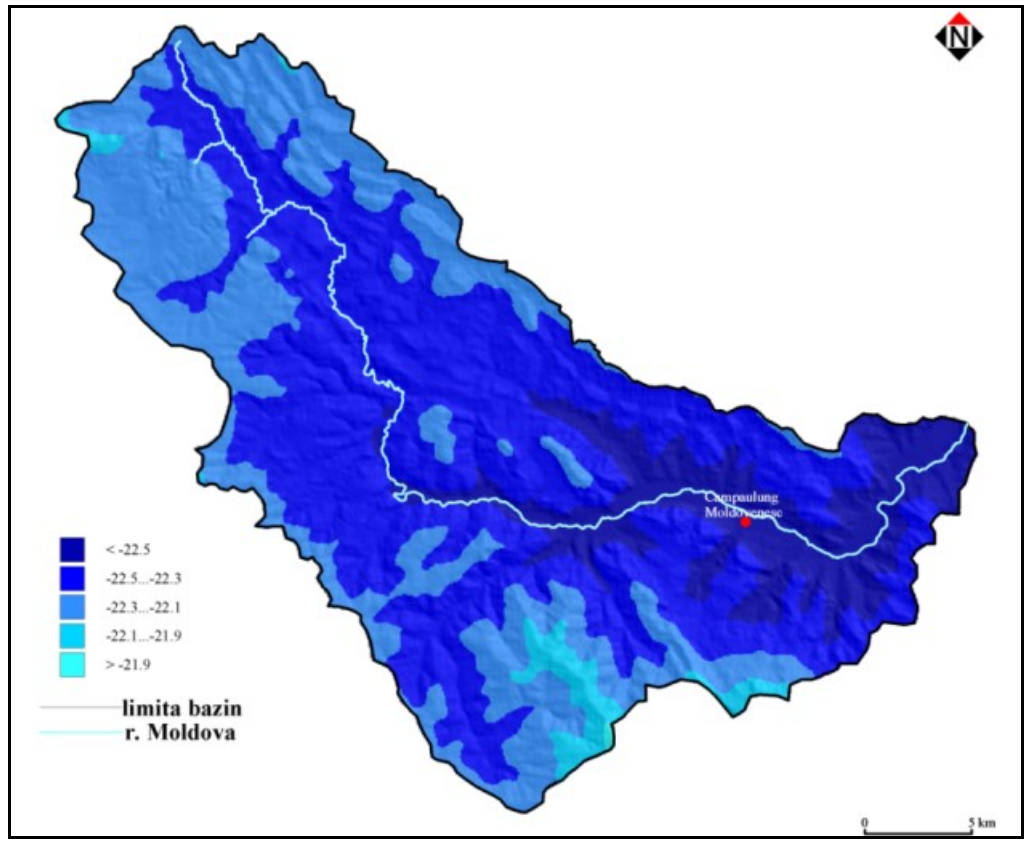

Fig.3 Distribution of the minimum absolute temperature in the coldest month of January(1961-1998)

As general notions, inversions of temperature represents a reverse layering of atmospheric thermal regime. Vertical thermal gradient exactly increases with altitude (quote from John O'sullivan, picked up after 1983, Yello Ţâştea et. Al. 1965 Neacşa, Frimescu, 1981). This can be inferred by analyzing the table below (tab 1) with multiannual average of the minimum absolute for the two meteorological stations, which are representative for the area studied, where it is 
observed that the thermal inversions are characteristic to winter's months when the depression's hearth is coolder with $2{ }^{\circ} \mathrm{C}$ in January, $0.4{ }^{\circ} \mathrm{C}$ in February, $0.1^{\circ} \mathrm{C}$ in December.

Tab 1 Multiannual average of minimum at the meteorological stations at Câmpulung Moldovenesc (1961-1998) and Rarău mountains (1961-1998)

\begin{tabular}{|l|c|c|c|c|c|c|c|c|c|c|c|c|}
\cline { 2 - 11 } \multicolumn{1}{c|}{} & I & II & III & IV & V & VI & VII & VIII & IX & X & XI & XII \\
\hline $\begin{array}{l}\text { RARAU } \\
(1961-1998)\end{array}$ & $\mathbf{- 1 8}$ & $-\mathbf{1 8 . 4}$ & $\mathbf{- 1 5 . 7}$ & $\mathbf{- 9 . 1}$ & $\mathbf{- 3 . 7}$ & $\mathbf{0 . 5}$ & $\mathbf{3 . 2}$ & $\mathbf{2 . 5}$ & $\mathbf{- 1 . 7}$ & $\mathbf{- 9}$ & $\mathbf{- 1 1 . 9}$ & $\mathbf{- 1 8 . 1}$ \\
\hline $\begin{array}{l}\text { CAMPULUNG MOLD } \\
(1961-1998)\end{array}$ & $\mathbf{- 2 0}$ & $\mathbf{- 1 8 . 8}$ & $\mathbf{- 1 4 . 5}$ & $\mathbf{- 5 . 3}$ & $\mathbf{- 0 . 4}$ & $\mathbf{3 . 6}$ & $\mathbf{5 . 8}$ & $\mathbf{4 . 4}$ & $\mathbf{- 0 . 4}$ & $\mathbf{- 5 . 7}$ & $\mathbf{- 1 1 . 6}$ & $\mathbf{- 1 8 . 7}$ \\
\hline
\end{tabular}

During the year within the Câmpulung Depression, the most frequent thermal inversions occur usually during the winter months (especially in JanuaryFebruary) and much rarer in December or March (tab 2).

Tab 2 Frequency of thermal inversions at Câmpulung Moldovenesc, 1961-1998

\begin{tabular}{|c|c|c|c|c|c|c|c|c|c|c|c|}
\hline I & II & III & IV & V & VI & VII & VIII & IX & X & XI & XII \\
\hline 72.4 & 46.4 & 30.1 & 7.1 & 17.7 & 3.6 & 10.5 & 14.3 & 17.6 & 17.9 & 53.9 & 60.6 \\
\hline
\end{tabular}

At the level of 24 hours it is clear that the most intense thermal inversions occur during the night, when the radiative balance is exclusive negative. To notice the fact, as Bogdan Octavia affirmed in , Climate risks in Romania ', that in carpathian lowland areas, inversion waves propagates from the NorthernNorthern-Eastern to Southern-Southern-Western. Is given to exemplify January 1965, when temperature inversions occurred on January 12 at Câmpulung Moldovenesc, where the temperature was $-17.0^{\circ} \mathrm{C}$ at 7 on the depression's hearth, and at meteorological station Rarău, it was about. 4 degrees higher.

As representative risks posed by these thermal inversions can be noted that amid atmospheric stability (atmospheric calm), due to industrial activities and especially, the fact that in the area that we are studied exist heating on the basis of wood (especially in rural areas), leading to some air pollution with various pollutants, which have repercussions on the elderly, children and people with respiratory conditions.

The effects of thermal inversions is harmful and for vegetation,if they occur in extraseason, when the plants begin their vegetative cycle. The worse is, if it is found in the atmosphere and a high amount of water vapors, in this way there is the risk of haze or smog, especially, in the afferent area of Moldova river, where, 
of course, also the humidity is higher compared to higher adjacent areas (Deia, Bodea, etc).

\section{The frost and rime}

Relating to Câmpulung Depression, the earliest ground frosts may occur in September, when can record and values of $-3.4^{\circ} \mathrm{C}$ at ground level. This is an average value, this being given below (table 3 ).

Table 3 Average multiannual values of soil temperature at Câmpulung Moldovenesc (1961-1998)

\begin{tabular}{|l|l|l|l|l|l|l|l|l|l|l|l|l|}
\hline C.M. & -4.5 & -2.8 & 1.1 & 8.0 & 14.3 & 19.0 & 20.5 & 19.6 & 13.8 & 7.9 & 3.1 & -4.0 \\
\hline
\end{tabular}

For Câmpulung Moldovenesc, and also the rest of the depressional areas from the studied area, frosts are a risk, when they occur during the extraseason, particularly in the months of April and May, the most later frosts, or in September (sometimes the frost may occur in the last days of the month of august) in the case of early frost. Specific to depressional areas from the mountain area of the Moldova river, the range of climatic risk represented by the frost factor is located between :-the most later frost, it is located between 8th-9TH [...]7-X; -the latest frost is represented by its appearance between 26-IV ... 31-V (fig. 4).

\begin{tabular}{|c|c|c|c|c|c|c|c|c|}
\hline \multicolumn{3}{|c|}{ early frost(autumn) } & \multirow{2}{*}{\multicolumn{3}{|c|}{$\begin{array}{l}\text { winter(no risk) } \\
\text { normal(no risk) }\end{array}$}} & \multicolumn{3}{|c|}{ later frost(spring) } \\
\hline \multicolumn{2}{|c|}{ high risk } & \multirow{2}{*}{$\begin{array}{c}\text { medium } \\
15-\mathrm{XI} \\
\end{array}$} & & & & \multirow{2}{*}{$\begin{array}{c}\text { medium } \\
3-\text { III } \\
\end{array}$} & \multicolumn{2}{|c|}{ high } \\
\hline 8-IX & $7-X$ & & & & & & 26-IV & $31-\mathrm{V}$ \\
\hline IX & $\mathbf{x}$ & XI & XII & I & II & III & IV & V \\
\hline
\end{tabular}

Fig. 4 The degree of risk represented by frost for Câmpulung Moldovenesc

For the area studied,the frost has negative consequences on the following plants, which are cultivated in the area, these being given below (tab. 4).

It is worth to notice the fact that the phenomenon of frost associated with other meteorological phenomenons such as drizzle,supercooled rain,soft snow, sleet, may also cause significant damage on society, by the fact that the combination of frost with above mentioned climatic phenomenons, leading to the freezing of water on wires or branches of trees and automatically lead to load them,and at long last, there is the risk that these (telephone cables, electricity cables, fruit tree branches, etc) to break away, causing a big chaos to society. 
Tab 4 Representation of the main plants and vegetables exposed to frost in the mountain basin of the Moldova river

\begin{tabular}{|c|c|c|c|c|c|c|}
\hline \multirow[b]{2}{*}{ Plant } & \multicolumn{2}{|c|}{ Rising } & \multicolumn{2}{|c|}{ Blooming } & \multicolumn{2}{|c|}{ Riping } \\
\hline & $1 *$ & $2 * *$ & $1 *$ & $2 * *$ & $1 *$ & $2 * *$ \\
\hline Sugar beet & -6 & -7 & - & -3 & - & - \\
\hline Carrot & -6 & -7 & - & - & - & - \\
\hline Cabbage & -9 & -10 & - & - & - & - \\
\hline Corn & -2 & -3 & -1 & -2 & -2 & -3 \\
\hline Potato & -2 & -3 & -1 & -2 & -1 & -2 \\
\hline Bean & -2 & -1.5 & -0.5 & -1 & -2 & - \\
\hline Curcubitacee & -0.5 & -1 & -0.5 & -1 & -0.5 & -1 \\
\hline
\end{tabular}

* Thermal limits that causes the start of injury $\left({ }^{\circ} \mathrm{C}\right)$

**) Thermal limits causing partial destruction of plants $\left({ }^{\circ} \mathrm{C}\right)$

Given the fact that specific to the area are grazing lands, early and late frosts,represent a high risk,because it can capture herds of sheeps or cattles in grazing areas in the moment they just were climbed for grazing or before the descent.

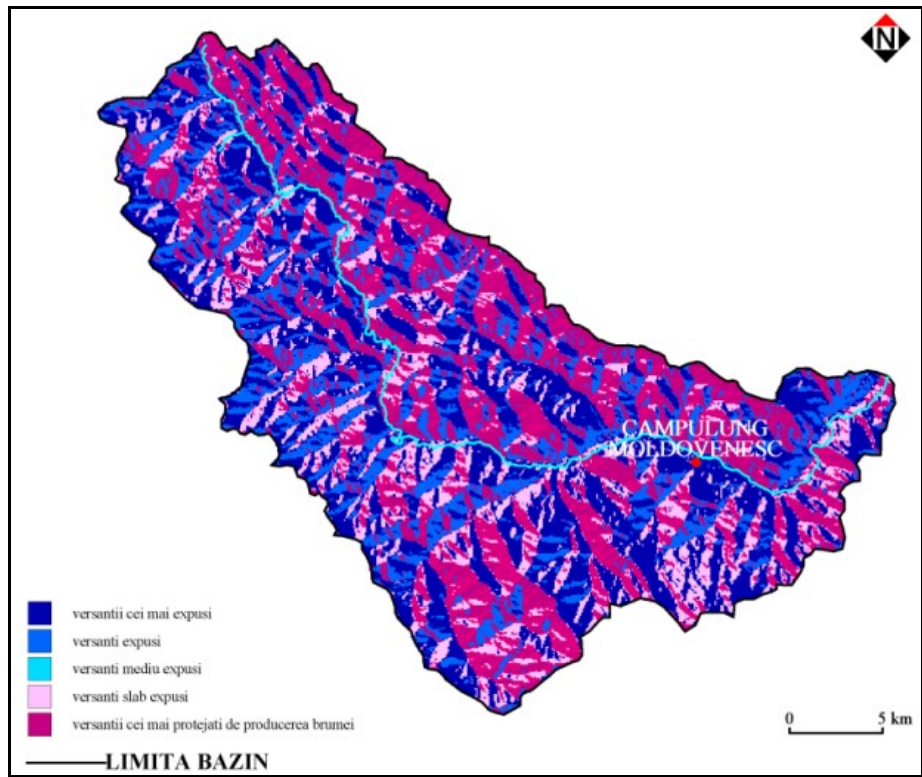

Fig. 5 Exposure of the slopes at the phenomenon of rime 
The rime manifests, as in the case of frost and depending of slopes' exposition, the degree of humidity of the atmosphere. In the studied area,the rime appears,with predilection, on slopes with northern and northern-eastern exhibition and finally,it appears and on the slopes with the southern and southern-western exhibition (fig. 5).

Thus, as it can be observed on the picture shown with areas exposed to the formation of rime (fig. 6), those who are most affected, togheter with the exposed ones, gathe approximately 64 percents, and the lowest percents are hold by the those moderately exposed, with about 4 percents. Poorly exposed slopes and those less exposed hold weights of 32-34 percents.

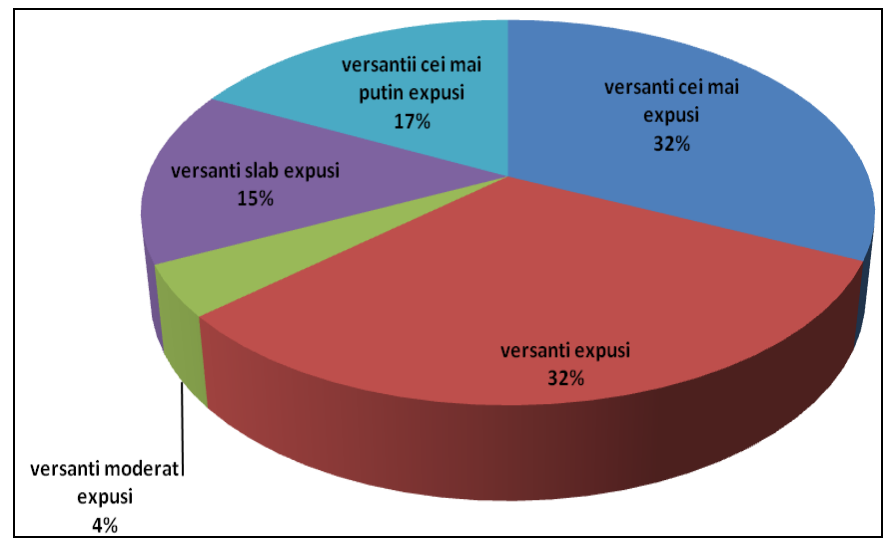

Fig. 6 The weight of exposed slopes to production of rime

Sometimes, due to the influence of the greenland anticyclone, the rime and the frost can occur the first time on the Western and Northern-Western of the slopes, in particular, on the Northern-Western and Western region (Moldova-Suliţa, Benia,Breaza de Sus,Breaza), these being a special case.

A special role in the manifestation process of frost and the formation of rime is given by soil type, forested areas, anthropogenic activity.

What can be said about rime in this individual case, at the level of the studied area, is the mention of the average date, when first appears on the rime, which is somewhere around 4-6 September (especially at Câmpulung Moldovenesc), following that in depressions Sadova, Pojorâta, that occur with a day earlier, and the later appearance of somewhere in the last decade of May. Very rare presence on can be reported (of course on the very restricted areas) even within the first 5 days of the month of June, especially in the regions with higher altitude of 650$700 \mathrm{~m}$. 
Although the speedy appearance of the first rime is possible in higher regions, the number of days with rimet is greatest in depressional regions compared to the highest of the surroundings, this due to the atmospheric calm on the existing depression's hearth, allowing its formation.

Tab 5 Average annual number of days with rime at Câmpulung Moldovenesc and Rarău 1961-1998

\begin{tabular}{|l|c|c|c|c|c|c|c|c|c|c|c|c|}
\cline { 2 - 12 } \multicolumn{1}{c|}{} & I & II & III & IV & V & VI & VII & VIII & IX & X & XI & XII \\
\hline C.M. & 1.4 & 1.9 & 5.7 & 5.4 & 1.1 & 0 & & & 2.1 & 9.6 & 9.3 & 4.3 \\
\hline RARĂU & 0.3 & 0.1 & 0.2 & 0.4 & 0.5 & 0.1 & & 0.1 & 2 & 4.6 & 3.3 & 0.7 \\
\hline
\end{tabular}

As you can see on the chart (fig. 7), we can observe a general tendency of decrease in the number of days with rime, that due to an increase in both DN 17 and on secondary arteries, this, in combination with the high number of construction, leaded to the creation of an island of heat in town, which can be explained by the reduction of the number of days with rime,this reduction can be observed after 1982 (excluding the maximum from 1984-1986), at which time the Câmpulung city was greatly expanded, influencing the local climate.

Besides, the same trend is observed and for the meteorological station Rarău, although at a more weighted scale compared with that from Câmpulung Moldovenesc.

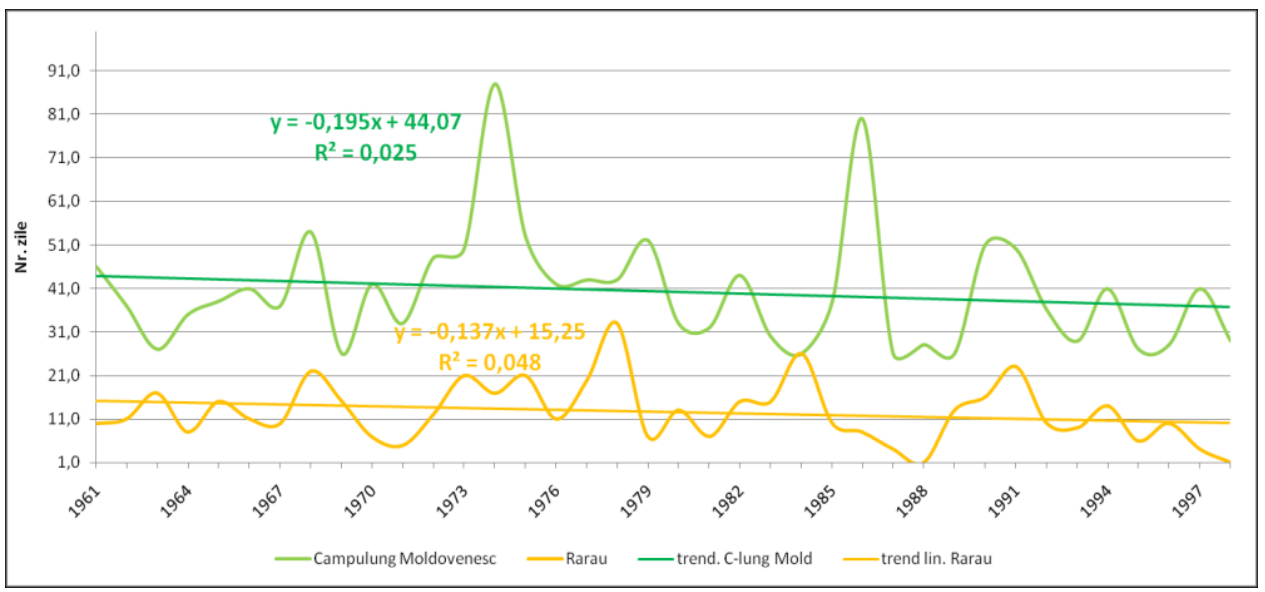

Fig. 7 The number of days with rime registered at Câmpulung Moldovenesc and Rarău (1961-1998) 
As risk, the rime has aproxymatively the same consequences as the frost, only that the rime affects subaerial area and certainly not underground areas (as in the case of frost).

\section{Conclusions}

As a result of this study, it seems that the most representative risks in the studied area during the cold season are those related to temperature,respectively, the occurrence of thermal inversions translated by dwelling the cold air on the depression's hearth in the context of the atmospheric calm associated anticyclonic conditions, with the highest frequency in the winter months, namely: January, February and December,but also in November and March.

This stability of air masses lead to intense pollution in lowland areas, the most affected being the Câmpulung Moldovenesc city,and in periods of transition, cold air invasions lead to injury and damage to crops and trees.

Aknowledgement:This work was published with the financial support of the project „Integrated system of improving the quality of doctoral and postdoctoral research in Romania and to promote the role of science in society", POSDRU/159/1.5/S/133652, financed by the European Social Fund, The sectoral Operational Programme Human Resources Development 2007-2013.

\section{References}

Apostol Liviu(1990), Anomalii ale temperaturii aerului pe teritoriul României, extras, tom XXXVII, Editura Universităţii, Bucureşti.

Apostol Liviu(2000) Precipitaţii atmosferice în Subcarpaţii Moldovei, Editura Universităţii, Suceava.

Apostol Liviu(2004), Clima Subcarpaţilor Moldovei, Editura Universităţii, Suceava

Bogadan Octavia(1978), Fenomene climatice de vară şi de iarnă,Editura Ştiinţifică şi Enciclopedică, Bucureşti.

Bogdan Octavia, Niculescu Elena(1999), Riscurile climatice din România, Editura Academiei Române, Bucureşti.

Rusu Constantin(2000), Rarău- Studiu de Geografie Fizică, Editura Universităţii „Al.I. Cuza", Iaşi.

Sfícă Lucian(2009), Culoarul Siretului. Studiu climatic, Iaşi.

Ştefan Sabina(2004), Fizica atmosferei, vremea şi clima, Editura Universităţii, Bucureşti.

Administrația Națională de Meteorologie(2008), Clima României, Editura Academiei române, București.

*** www.geo-spaţial.org

****www.glcf.umiacs.umd.edu 
$* * *$ http://rapidfire.sci.gsfc.nasa.gov/

$* * *$ www.wetterbote.de

$* * *$ www.wetterpate.de

$* * *$ www.wetterzentrale.de

$* * *$ www.wetter3.de/archive 